\title{
Modification of Glassy Carbon Electrode with Palladium Doped Conducting Poly(thionine) Film Songül Kırlak Kara ${ }^{1}$ iD, Mutlu Sönmez Çelebi ${ }^{2}$
}

${ }^{1}$ Ordu University, Faculty of Science and Arts, Department of Chemistry, Ordu ${ }^{2}$ Ordu University, Faculty of Science and Arts, Department of Chemistry, Ordu Geliş Tarihi / Received Date: 03.11.2021 Kabul Tarihi / Accepted Date: 01.12.2021

\section{Abstract}

Glassy carbon electrode was modified with Pd particles using a conducting poly(thionine) as the support material. Polymerization of thionine was carried by electrochemical process from aqueous thionine acetate solution using cyclic voltammetry. $\mathrm{K}_{2} \mathrm{PdCl}_{4}$ was used as the $\mathrm{Pd}$ precursor and the $\mathrm{Pd}$ immobilization was performed with constant potential electrolysis. The modified electrode was characterized electrochemically using cyclic voltammetry and electrochemical impedance spectroscopy methods. The results revealed that the modification process significantly increases the conductivity properties of the electrode material.

Keywords: electrode modification, poly(thionine), palladium particles

\section{Camsı Karbon Elektrotun Paladyum Katkılı iletken Poli(tiyonin) Filmi ile Modifiye Edilmesi}

\section{Özet}

Camsı karbon elektrot iletken poli(tiyonin) destek malzemesi varlığında Pd tanecikleriyle modifiye edilmiştir. Tiyoninin polimerizasyonu elektrokimyasal yolla sulu tiyonin asetat çözeltisinde dönüşümlü voltametri kullanılarak gerçekleştirilmiştir. Pd kaynağı olarak $\mathrm{K}_{2} \mathrm{PdCl}_{4}$ kullanılmış ve $\mathrm{Pd}$ immobilizasyonu sabit potansiyelde elektroliz ile yürütülmüştür. Modifiye elektrotun karakterizasyonu elektrokimyasal olarak dönüşümlü voltametri ve elektrokimyasal empedans spektroskopisi yöntemleriyle gerçekleştirilmiştir. Elde edilen sonuçlar, modifikasyon işleminin elektrot malzemesinin iletkenlik özelliklerini önemli ölçüde arttırdığını göstermiştir.

Anahtar Kelimeler: elektrot modifikasyonu, poli(tiyonin), paladyum tanecikleri 


\section{Introduction}

In the last few decades, chemically modified electrodes (CMEs) are attracting more and more attention as they enable electrochemists to work with numerous alternative materials that can be designed for specific purposes. The term CME has first been introduced by Murray and co-workers in 1975 to describe electrodes that have foreign molecules immobilized on their surfaces (Moses et al., 1975; Snell \& Keenan 1979). With the help of the modification process, it is possible to transfer the physicochemical properties of the modifier to the electrode surface (Abruna, 1988). This way, selectivity and sensitivity can be achieved for various purposes such as electrocatalysis (Çelebi et al., 2008; Sönmez Çelebi et al., 2020), electroanalysis (Singh et al., 2017; Wang et al., 2021) and even specific applications such as controlled drug delivery systems (Herrera et al 2018; Li et al 2018). On the other hand, metal nanoparticles have been objects of catalysis studies and materials science where they find wide application for designing advanced electrode materials (Kralik \& Biffis, 2001). The features of the metal nanoparticles are strongly influenced by the microenvironment surrounding them and often a suitable support is needed to obtain the desired material with enhanced stability. Conducting polymers are among the most used support materials for designing nanoparticle modified electrodes as they both serve as a stabilizing matrix for the metal nanoparticles and a conducting porous structure for increasing the surface area of the electrode (Çelebi, 2016; Ghosh et al., 2015).

In this work, we prepared a poly(thionine) (PTH) modified a glassy carbon electrode decorated with palladium ( $\mathrm{Pd}$ ) particles through a simple electrochemical route. For this purpose, we first coated the electrode with conducting PTH film by cyclic voltammetry technique followed by immobilization of the $\mathrm{Pd}$ particles from aqueous solution by constant potential electrolysis. For characterization of the modified electrode, we used cyclic voltammetry and electrochemical impedance methods. We also studied the effect of activation of the GCE for the immobilization of the polymer film onto the electrode material. Ultimately, our goal is to use the Pd@PTH modified GCE for designing an amperometric biosensor for hydrogen peroxide detection.

\section{Materials and Methods}

\section{Materials and Methods}

PTH was synthesized according to the procedure described by Yang et al. (1999). Thionine acetate, $\mathrm{H}_{2} \mathrm{SO}_{4}, \mathrm{~K}_{2} \mathrm{PdCl}_{4}, \mathrm{~K}_{3} \mathrm{Fe}(\mathrm{CN})_{6}$ and $\mathrm{K}_{4} \mathrm{Fe}(\mathrm{CN})_{6}$ were obtained from Sigma-Aldrich and used as received. Triple distilled water was used for aqueous solutions. Solutions were saturated with high purity nitrogen gas before the experiments to remove the dissolved oxygen. All experiments were carried out at ambient temperature.

Electrochemical experiments were performed using $\mathrm{CHI}$ 600E electrochemical workstation. IVIUM Pocket Stat impedance analyzer was used for electrochemical impedance spectroscopy (EIS) studies. A three-electrode system glass cell was used with a glassy carbon working electrode (GCE, $3 \mathrm{~mm}$ in diameter). A saturated calomel electrode (SCE) was used as the reference electrode and a Pt wire was used as the counter electrode.

\section{Results and Discussion}

Immobilization of PTH film on GCE was carried out via cyclic voltametric scans in $0.1 \mathrm{M}$ thionine acetate solution containing $0.5 \mathrm{M} \mathrm{H}_{2} \mathrm{SO}_{4}$ as the supporting electrolyte. The potential window was between potentials $-0.4 \mathrm{~V}-+0.1 \mathrm{~V}$ vs. SCE. Growth of the polymer film on the electrode surface is given in Figure 1. 


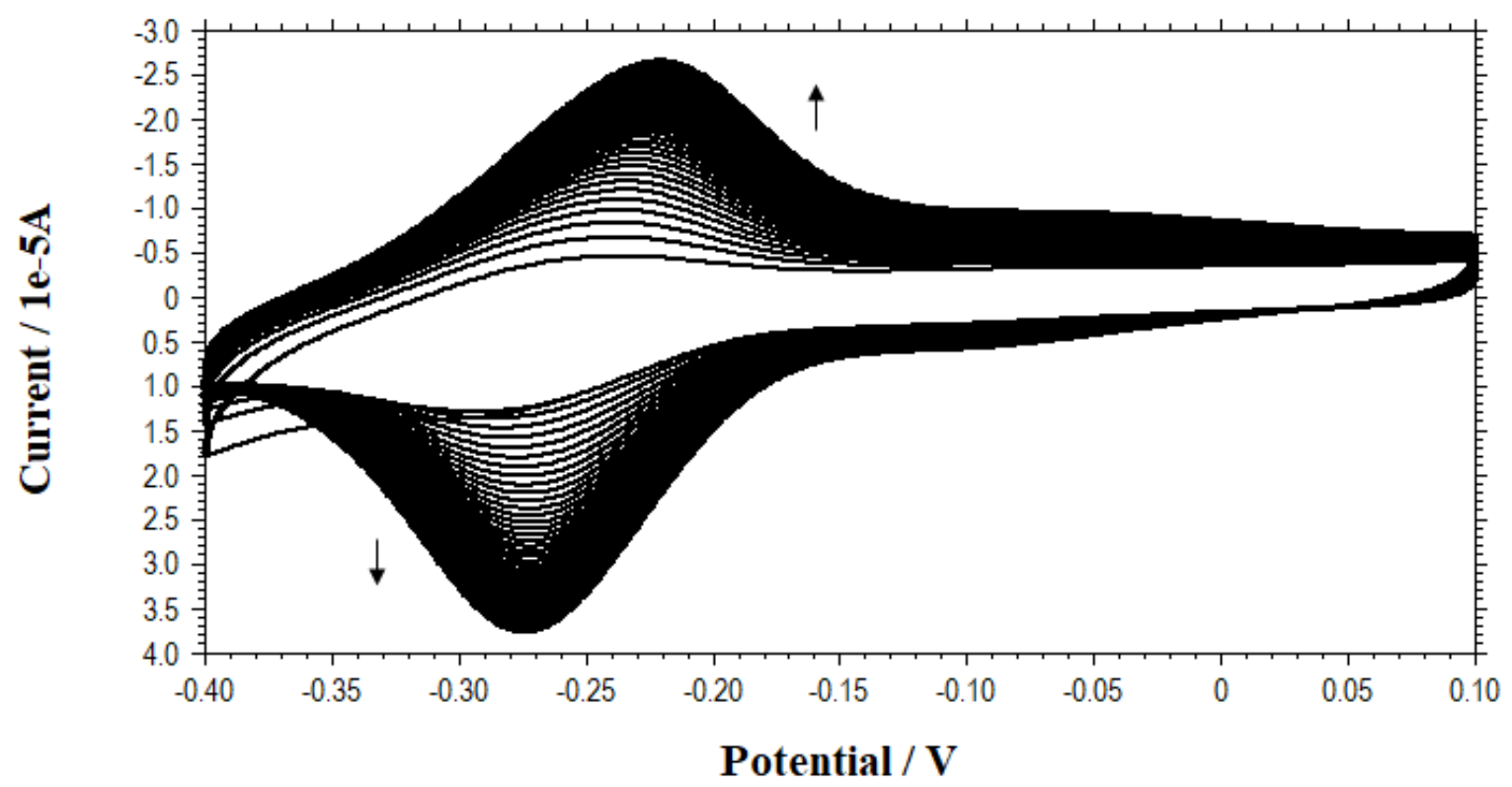

Figure1. Polimerization of Thionine from $0.1 \mathrm{Mm}$ Thionine Acetate Solution Containing $0.5 \mathrm{M} \mathrm{H}_{2} \mathrm{SO}_{4}$ as the Supporting Electrolyte (Scan rate: $100 \mathrm{mV} \mathrm{s}^{-1}$ )

To confirm the formation of the PTH film, we recorded the CV of the resulting film in $0.5 \mathrm{M} \mathrm{H}_{2} \mathrm{SO}_{4}$ solution (Figure 2). When we examine the $\mathrm{CV}$, oxidation and reduction peaks of the polymer are observed at potentials $+0.20 \mathrm{~V}$ and $+0.23 \mathrm{~V}$ respectively, which are clearly different than those of the monomer. Therefore, the CV in the blank solution is the proof of the formation of the polymer film on GCE.

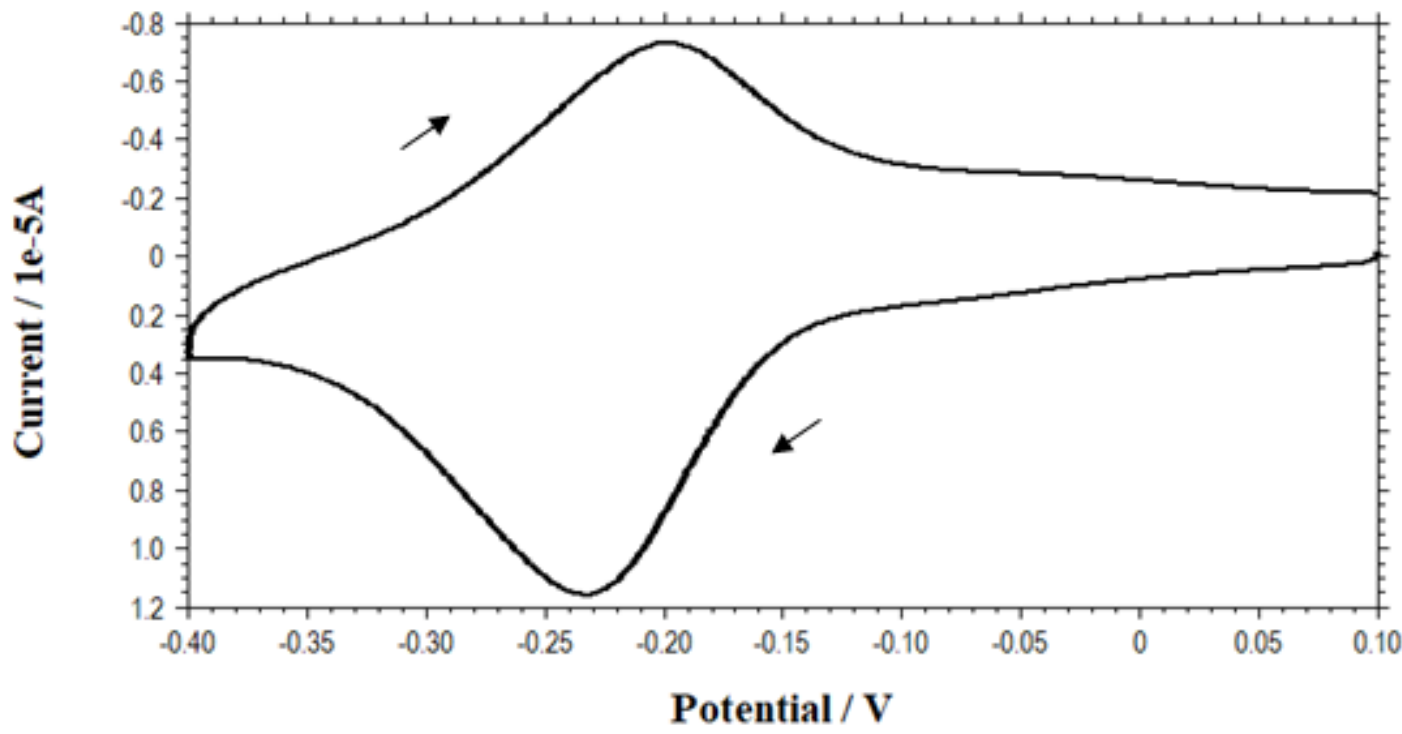

Figure2. $\mathrm{CV}$ of the Polymer Coated GCE in $0.5 \mathrm{M} \mathrm{H}_{2} \mathrm{SO}_{4}$ (Scan rate: $100 \mathrm{mV} \mathrm{s}^{-1}$ )

GCE, which is produced through pyrolysis of polymer resin is well known with its good conductivity (Jenkins and Kawamura 1976). This feature makes the GCE a preferred electrode material for sensor studies. Moreover, electrochemical pretreatment which is also referred to as activation, results in significant improvement in the physical and electrochemical properties of the electrode material (Thiagarajan et al 2009). Therefore, in this work, we studied the effect of the activation of the GCE. Activation was performed prior to the electro polymerization process by applying constant potential electrolysis to the uncoated electrode for $5 \mathrm{~min}$ at $+1.5 \mathrm{~V}$ in $0.1 \mathrm{mM}$ thionine acetate solution containing $0.5 \mathrm{M} \mathrm{H}_{2} \mathrm{SO}_{4}$. When we compared the polymerization profiles of the activated and the 
unactivated electrodes, it was clear that the activation process was enabling much better electrochemical response during the polymerization (Figure 3).

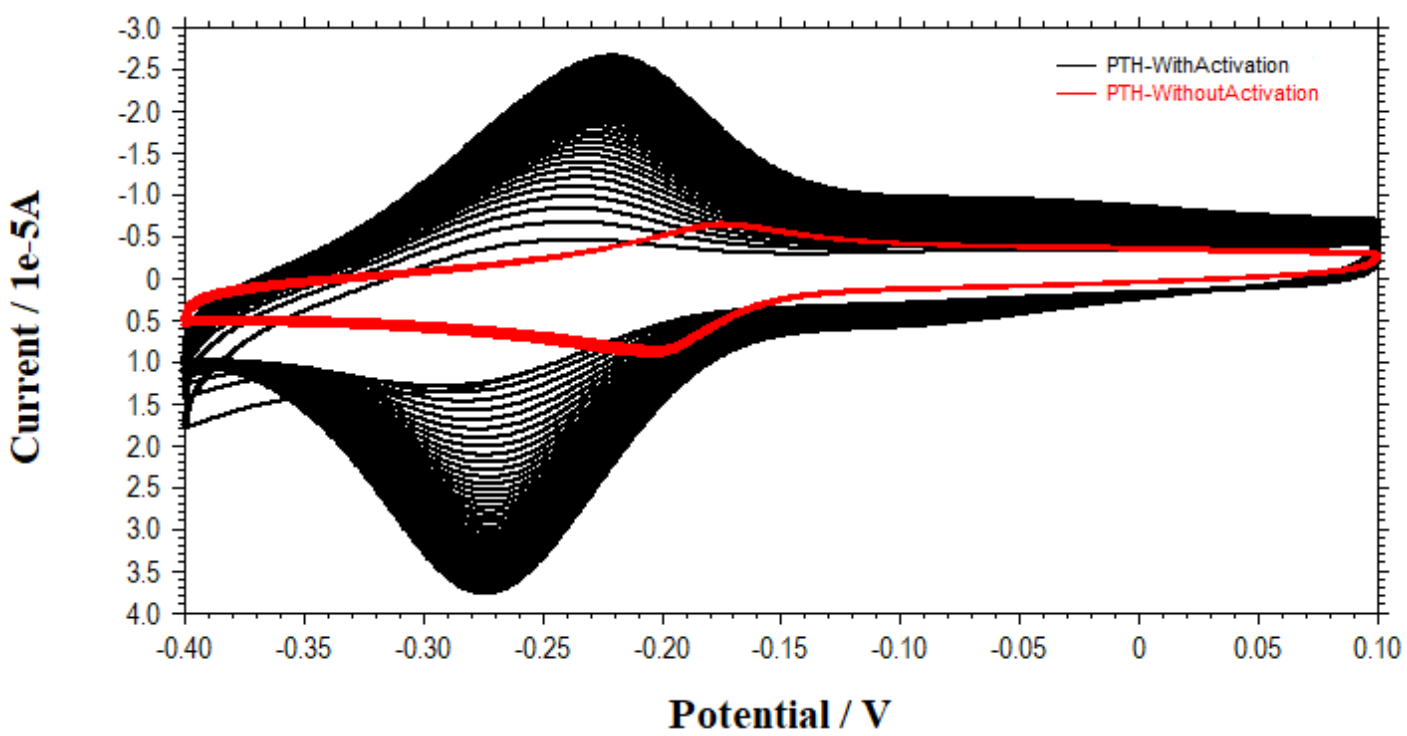

Figure3. Polimerization Profiles on GCE Under Activated (black) and Unactivated (red) Conditions (Scan rate: $100 \mathrm{mV} \mathrm{s}^{-1}$ )

$\mathrm{K}_{2} \mathrm{PdCl}_{4}$ solution was used as the precursor to immobilize Pd particles to the polymer coated GCE. For this purpose, PTH coated working electrode was immersed in an aqueous $2.0 \mathrm{mM} \mathrm{K}_{2} \mathrm{PdCl}_{4}$ solution without supporting electrolyte and electrolysis was performed at $-0.8 \mathrm{~V}$ constant potential to reduce the Pd particles directly to the polymer film matrix; no further reduction was applied. After this step, CV of the resulting Pd@PTH modified GCE in $0.5 \mathrm{M} \mathrm{H}_{2} \mathrm{SO}_{4}$ revealed the formation of the Pd particles on the polymer coated electrode (Figure 4).

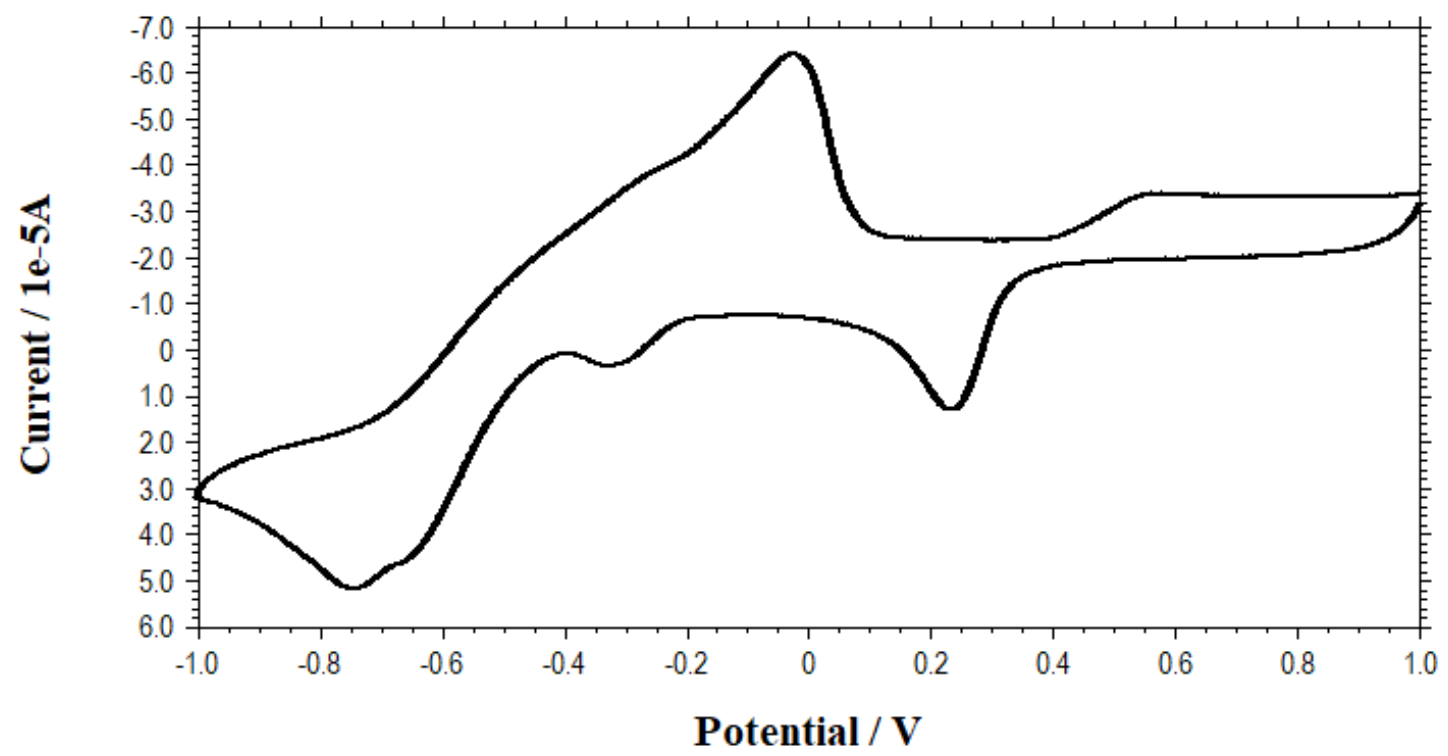

Figure4. CV of Pd@PTH Modified GCE in $0.5 \mathrm{M} \mathrm{H}_{2} \mathrm{SO}_{4}$ (Scan rate: $100 \mathrm{mV} \mathrm{s}^{-1}$ )

Finally, we characterized the prepared modified electrode using EIS method. In Figure 5, Nyquist plots of uncoated GCE, PTH coated GCE and Pd@PTH modified GCE recorded in $5.0 \mathrm{mM} \mathrm{Fe}(\mathrm{CN})_{6}^{3-/ 4-}$ solution containing $0.1 \mathrm{M} \mathrm{KCl}$ in the frequency range $0.01-105 \mathrm{~Hz}$ (amplitude $=10 \mathrm{mV}$, open circuit potential) are given. According to the semi-circles seen in the figure, the electron transfer resistance (Rct) values 
of the surface decrease significantly as a result of the modification process, which reveals that the conductivity increases significantly. Moreover, to display the role of the PTH support material for Pd particles, the Nyquist plots of the Pd immobilized GCE with and without the PTH film was recorded under the same experimental parameters (Figure 6). As clearly seen, the use of PTH as the support material for Pd particles significantly increases the conductivity properties of the film and facilitates the diffusion of the ferricyanide ions to the electrode surface.

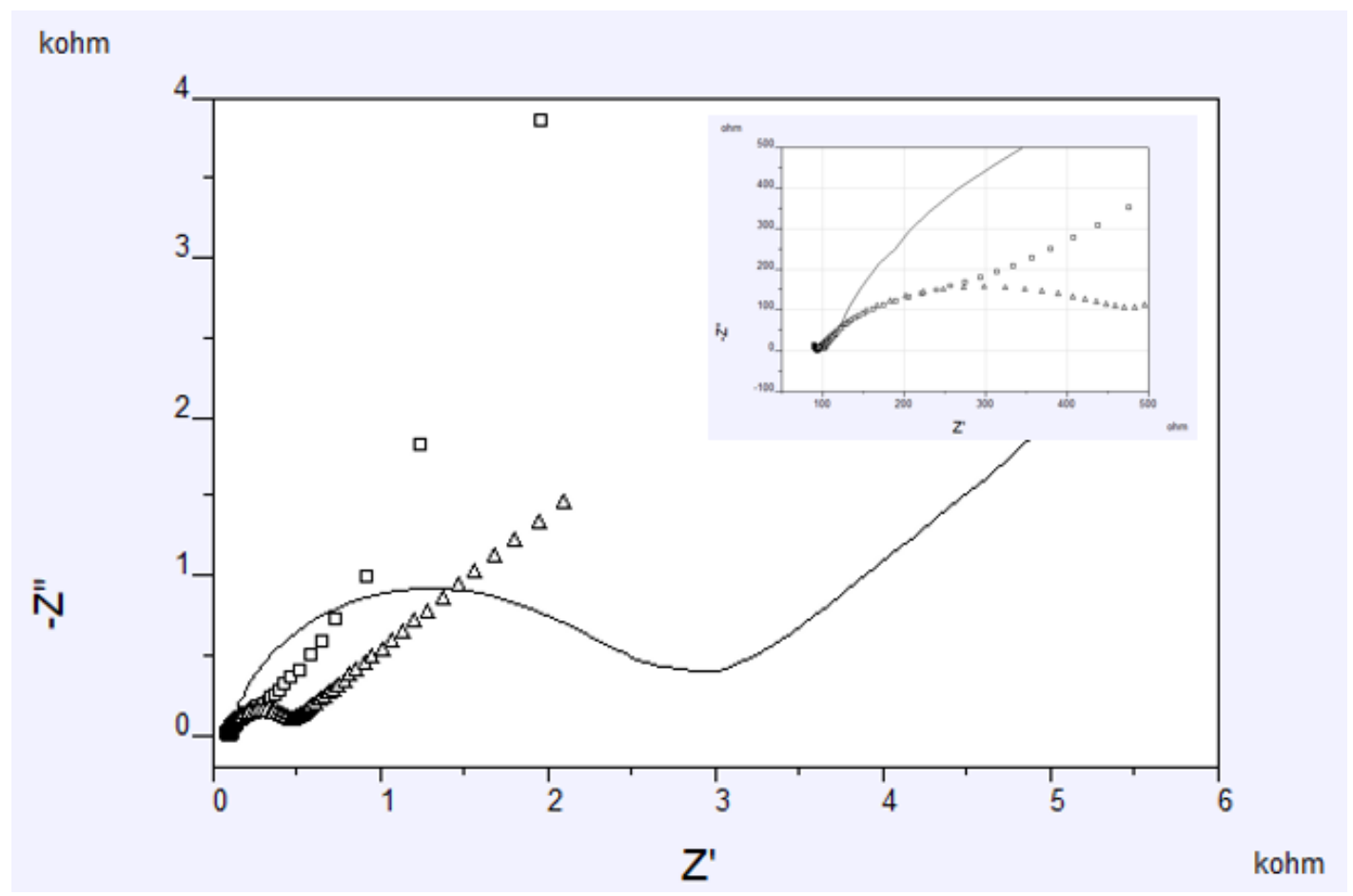

Figure5. Nyquist Plots for Uncoated GCE(-) , PTH Coated GCE $(\Delta)$ and Pd@PTH Coated GCE ( $\square)$ in 5.0 $\mathrm{mM} \mathrm{Fe}(\mathrm{CN})_{6}^{3-/ 4-}$ Solution

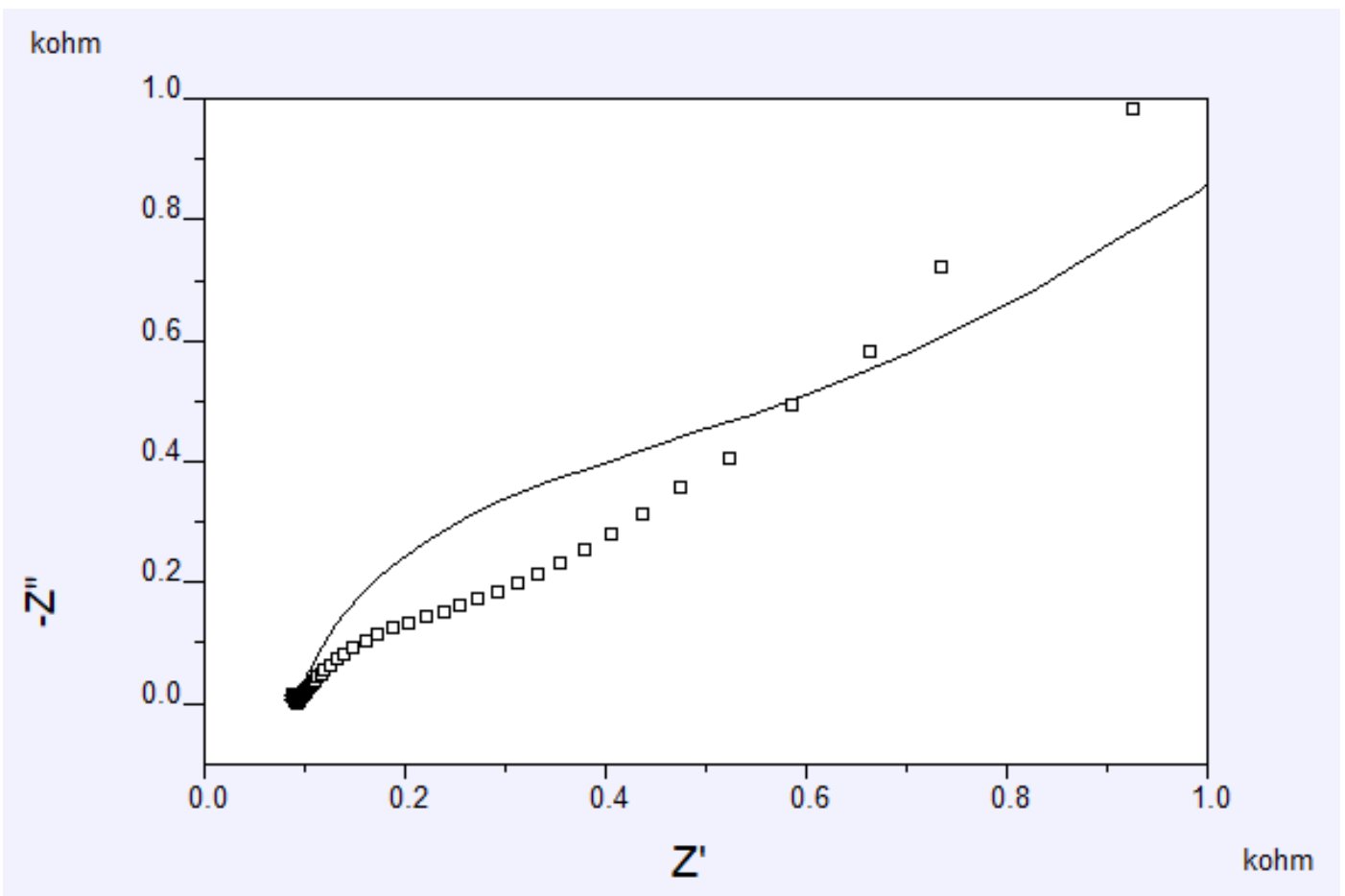

Figure6. Nyquist Plots for Pd Modified GCE(-) and Pd@PTH Coated GCE ( $\square$ ) in 5.0 mM Fe(CN)6 ${ }_{6}^{3-/ 4-}$ Solution 


\section{Conclusion}

We described the preparation of Pd@PTH modified GCE using a two-step simple procedure. Activation of the working electrode prior to the polymerization process improved the polymerization of thionine and the prepared modified electrode exhibited improved conductivity. It can be concluded that the PTH conducting film can be used as a favorable support material serving as a suitable matrix for immobilization of Pd particles. The prepared modified electrode system is planned to be optimized for designing an electrochemical sensor for selective determination $\mathrm{H}_{2} \mathrm{O}_{2}$ in aqueous medium.

\section{Funding}

This study was supported by the Scientific Research Projects Coordination Department of Ordu University (ODÜBAP) with grant number: TF-1614. The study was produced from the master's thesis titled "Determination of $\mathrm{H}_{2} \mathrm{O}_{2}$ with Poly(thionine) supported palladium nanoparticles" which was carried out by Songül Kırlak Kara under the supervision of Assoc. Dr. Mutlu Sönmez Çelebi (Thesis No. 541242).

\section{Author contributions}

Songül Kırlak Kara, performed the experiments and collected the data. Mutlu Sönmez Çelebi, prepared the experimental environment, supervised the experimental process, and evaluated the results. The authors co-authored, read, and approved the article.

\section{Ethics statement}

There are no ethical issues with the publication of this article.

\section{Conflict of Interest}

The authors state that there is no conflict of interest.

\section{ORCID}

Songül Kırlak Kara (D) https://orcid.org/0000-0001-5432-1721

Mutlu Sönmez Çelebi (D) https://orcid.org/0000-0002-8816-6763

\section{References}

Abruna, H.D. (1988). Coordination Chemistry in Two Dimensions: Chemically Modified Electrodes. Coordination Chemistry Reviews, 86, 135-189. https://doi.org/10.1016/0010-8545(88)85013-6

Çelebi, M. S., Pekmez, K., Özyörük, H., \& Yıldız, A. (2008). Preparation and physical/electrochemical characterization of Pt/poly (vinylferrocenium) electrocatalyst for methanol oxidation. Journal of Power Sources, 183(1), 8-13. https://doi.org/10.1016/j.jpowsour.2008.05.010

Çelebi, M. S. (2016). Energy Applications: Fuel Cells. Advanced Electrode Materials (Edited by A. Tiwari, F. Kuralay, L. Uzun), Wiley-VCH, Weinheim, 397-434.

Ghosh, S., Teillout, A. L., Floresyona, D., de Oliveira, P., Hagège, A., \& Remita, H. (2015). Conducting polymer-supported palladium nanoplates for applications in direct alcohol oxidation. International Journal of Hydrogen Energy, 40(14), 4951-4959. https://doi.org/10.1016/j.ijhydene.2015.01.101

Herrera, P. A. H., Santana, N. C., \& Martinez, J. A. (2018). Electrosynthesis and DSC Characterization of Doped Polypyrrole Films with Sodium Salicylate and Sodium Ibuprofen on the Mg Alloy AZ31. ECS Transactions, 84(1), 243. https://doi.org/10.1149/08401.0243ecst

Jenkins, G. M., \& Kawamura, K. (1976). Polymeric carbons: Carbon fibre, glass and char. Cambridge University Press. 
Kralik, M., \& Biffis, A. (2001). Catalysis by metal nanoparticles supported on functional organic polymers. Journal of Molecular Catalysis A: Chemical, 177(1), 113-138. https://doi.org/10.1016/S1381-1169(01)00313-2

Li, S., Jasim, A., Zhao, W., Fu, L., Ullah, M. W., Shi, Z., \& Yang, G. (2018). Fabrication of ph-electroactive bacterial cellulose/polyaniline hydrogel for the development of a controlled drug release system. Es mater. Manuf., 1, 41-49. https://doi.org/10.30919/esmm5f120

Moses, P. R., Wier, L., \& Murray, R. W. (1975). Chemically modified tin oxide electrode. Analytical Chemistry, 47(12), 1882-1886. https://doi.org/10.1021/ac60362a043

Singh, P., Srivastava, S., \& Singh, S. K. (2017). H2O2 sensing through electrochemically deposited thionine coated ITO thin film. Cellular and Molecular Biology, 63(6), 56-59. http://dx.doi.org/10.14715/cmb/2017.63.6.13

Snell, K. D., \& Keenan, A. G. (1979). Surface modified electrodes. Chemical Society Reviews, 8(2), 259282. https://doi.org/10.1039/CS9790800259

Sönmez Çelebi, M., Kırlak Kara S., \& Çoşkun Kurt, N. (2020). Electrocatalytic oxidation of formic acid using Pt nanocatalyst supported on PVF-PANI composite. Ordu University Journal of Science and Technology, 10(1), 13-22. https://dergipark.org.tr/en/pub/ordubtd/issue/55660/755194

Thiagarajan, S., Tsai, T. H., \& Chen, S. M. (2009). Easy modification of glassy carbon electrode for simultaneous determination of ascorbic acid, dopamine, and uric acid. Biosensors and Bioelectronics, 24(8), 2712-2715. https://doi.org/10.1016/j.bios.2008.12.010

Wang, Y., Zhang, Y., Wang, Y., Zhu, R., Chen, Y., Liu, X., Xu, J., Li, M., \& Wang, D. (2021). Urea detection of electrochemical transistor sensors based on polyanline (PANI)/MWCNT/cotton yarns. Electroanalysis. 33, 1-12. https://doi.org/10.1002/elan.202100303

Yang, R., Ruan, C., Dai, W., Deng, J., \& Kong, J. (1999). Electropolymerization of thionine in neutral aqueous media and $\mathrm{H} 2 \mathrm{O} 2$ biosensor based on poly (thionine). Electrochimica Acta, 44(10), 15851596. https://doi.org/10.1016/S0013-4686(98)00283-7 